\title{
Hydraulic Fracturing as a Method for the Disposal of Volatile Radioactive Wastes
}

\author{
J. H. Shaffer \\ J. O. Blomeke
}

\section{MASTER}

\section{OAK RIDGE NATIONAL LABORATORY} OPERATED BY UNION CARBIDE CORPORATION · FOR THE DEPARTMENT OF ENERGY 


\section{DISCLAIMER}

This report was prepared as an account of work sponsored by an agency of the United States Government. Neither the United States Government nor any agency Thereof, nor any of their employees, makes any warranty, express or implied, or assumes any legal liability or responsibility for the accuracy, completeness, or usefulness of any information, apparatus, product, or process disclosed, or represents that its use would not infringe privately owned rights. Reference herein to any specific commercial product, process, or service by trade name, trademark, manufacturer, or otherwise does not necessarily constitute or imply its endorsement, recommendation, or favoring by the United States Government or any agency thereof. The views and opinions of authors expressed herein do not necessarily state or reflect those of the United States Government or any agency thereof. 


\section{DISCLAIMER}

Portions of this document may be illegible in electronic image products. Images are produced from the best available original document. 
Printed in the United States of America. Available from National Technical Information Service

U.S. Department of Commerce

5285 Port Royal Road, Springfield, Virginia 22161

Price: Printed Copy $\$ 4.50$; Microfiche $\$ 3.00$

This report was prepared as an account of work sponsored by an agency of the United States Government. Neither the United States Government nor any agency thereof, nor any of their employees, contractors, subcontractors, or their employees, makes any warranty, express or implied, nor assumes any legal liability or responsibility for any third party's use or the results of such use of any information, apparatus, product or process disclosed in this report, nor represents that its use by such third party would not infringe privately owned rights. 
ORNL/TM-6931

Dist. Category UC-70

Contract No. W-7405-eng-26

CHEMICAL TECHNOLOGY DIVISION

Nuclear Fue1 and Waste Programs

Airborne Waste Program (IDO/ACC)

(Subtask ON 4.6.5.4 AG)

HYDRAULIC FRACTURING AS A METHOD FOR THE DISPOSAL OF

VOLATILE RADIOACTIVE WASTES

J. H. Shaffer

J. 0. Blomeke

Date Published - August 1979

NOTICE This document contains information of a preliminary nature. It is subject to revision or correction and therefore does not represent a final report.

OAK RIDGE NATIONAL LABORATORY

Oak Ridge, Tennessee 37830

operated by

UNION CARBIDE CORPORATION

for the

DEPARTMENT OF ENERGY 


\section{THIS PAGE}

WAS INTENTIONALLY

LEFT BLANK 
ABSTRACT ............................ . . . . 1

1. INTRODUCTION . . . . . . . . . . . . . . . . . 1

2. THE HYDROFRACTURE PROCESS . . . . . . . . . . . . . 2

2.1 Site Selection .................. 3

2.2 Operational Parameters ............. 3

3. WASTE DISPOSAL OPTIONS .................. 4

3.1 Immobilization of Volat1le Wastes . . . . . . . . . 4

3.2 Volatile Waste Disposal by the Hydrofracture Process . 5

3.2.1 Disposal as liquids . . . . . . . . . . 5

3.2.2 Disposal as solids . . . . . . . . . . . 6

3.2.3 Disposal as gases ............. 6

4. ENTRAINMENT OF KRYPTON IN HYDROFRACTURE GROUTS . . . . . . . 7

4.1 Production of $85 \mathrm{Kr}$. . . . . . . . . . . . . . . 7

4.2 Krypton Solubility in Grout Mixes . . . . . . . . . 8

4.3 Gas Injection Parameters . . . . . . . . . . . . 8

4.4 Release Rate Considerations............ 9

5. CONCLUSIONS AND RECOMMENDATIONS . . . . . . . . . . . 10

6. ACKNOWLEDGMENTS . . . . . . . . . . . . . 12

7. REFERENCES ........................ 12 
HYDRAULIC FRACTURING AS A METHOD FOR THE DISPOSAL OF

VOLATILE RADIOACTIVE WASTES

J. H. Shaffer

J. 0. Blomeke

\begin{abstract}
This report proposes the further development of the hydrofracture process at the Oak Ridge National Laboratory for the permanent disposal of volatile radioactive wastes. The assessment of this method has included the disposal of ${ }^{129} \mathrm{I},{ }^{14} \mathrm{C},{ }^{85} \mathrm{Kr}$, and tritium. It is recommended that additional studies be made of the feasibility of injecting krypton, as an admixture with xenon, directly into the hydrofracture grout stream for disposal in deep impermeable shale formations. The annual production of $85 \mathrm{Kr}$ from reprocessing 1500 metric tons of fuel would create a void of $\leq 1 \%$ when injected into the grout mixture used in a typical hydrofracture operation.
\end{abstract}

\title{
1. INTRODUCTION
}

Volatile radioactive wastes will normally be generated by head-end processes of planned nuclear fuel reprocessing facilities. These wastes must be removed from the plant off-gas streams to prevent their release to the atmosphere or combination with other plant streams. Although methods for their recovery from these streams are reasonably welldeveloped conceptual methods for their permanent disposal have typically followed criteria established for wastes having much higher levels of radioactivity. This technology has generally considered the immobilization of these volatile materials in forms that may be committed to longterm storage and eventual disposal. However, proposed methods for permanent waste disposal either have been internationally unacceptable or insufficiently developed for critical appraisal. Of the methods under current development, storage and/or disposal in deep geological formations or arid regions represents the most realistic solution for 
general disposal of radioactive wastes. ${ }^{1}$ The disposal of intermediatelevel liquid wastes ( $<1.5 \times 10^{-6}$ to $2 \mathrm{Ci} / \mathrm{gal}$ ) into deep shale formations by the hydrofracture process has been used routinely to dispose of waste solutions generated at the Oak Ridge National Laboratory (ORNL). ${ }^{2}$ The extension of this waste disposal method to include volatile radioactive wastes is examined in this report.

The disposal of noble-gas fission products by the hydrofracture process was considered in a general assessment of the feasibility of underground storage and disposal of noble-gas fission products. ${ }^{3}$ The consensus of the report, with respect to the hydrofracture operation, is that the technology of this method has not been sufficiently developed for adequate appraisal. Thus, the purpose of this study is to relate requirements for the disposal of volatile radioactive wastes with operating parameters of the hydrofracture facility at ORNL.

\section{THE HYDROFRACTURE PROCESS}

Hydraulic fracturing was originally developed by the petroleum industry as a means of improving oil recovery from wells. Its use as a waste disposal method was recognized in more recent applications for discarding hazardous chemicals. These operations have normally been carried out in permeable rock formations to utilize the pore structure for trapping the liquid chemical waste. The program conducted at ORNL ditters in that aqueous radioactive wastes have been mixed with cement to form a grout which is injected into an impermeable shale formation well-below ground water level. ${ }^{4}$

Development of the hydrofracture process at ORNL began in 1959 with an evaluation of geological requirements, development of the grout mixture, and design of the facility. ${ }^{5-7}$ Large-scale injections were made to evaluate the process and equipment under proposed operating conditions. 8 This facility has been used for the routine disposal of intermediateleve1 liquid wastes since $1966 .{ }^{4}$ Design and installation of a new facility with a service life of about 30 years ( 100 injections at anticipated disposal rates) is essentially complete. ${ }^{9}$ 


\subsection{Site Selection}

The selection of potential sites for hydraulic fracturing operations may be guided by basic criteria established for the qualification of the Oak Ridge facility. A portion of the Oak Ridge Department of Energy reservation is underlain by thick Conasuaga formation shales. The upper portion of this shale formation is high-integrity, nonfractured, dense gray shale that is 600 to $700 \mathrm{ft}$ thick. This is underlain by approximately $300 \mathrm{ft}$ of red shale composed of thin, horizontally oriented beds. Fractures induced in this formation follow the horizontal bedding planes. Typical grout injections propagate formation fractures out to radial distances of approximately $1500 \mathrm{ft}$ (grout permeation to about $500 \mathrm{ft}$ ), with a maximum uplift of less than 0.2 in. at the injection site; thus, repeated injections are possible. As many as four injections have been made within 10-ft elevation intervals in the red shale formation. Potentially available sites exist in the Appalachian, Illinois, and Michigan basins, much of the Gulf Coast, and the Pierre and Manchos shale of Colorado and adjacent areas. ${ }^{3}$

\subsection{Operational Parameters}

Current operations of the hydrofracture process at ORNL are based on an approximate $80,000 \mathrm{gal}\left(303 \mathrm{~m}^{3}\right)$ of liquid waste per injection. ${ }^{4}$ This volume represents the annual accumulation of intermediate-level liquid wastes at ORNL after their evaporation to activity levels of about 0.2 to $2.0 \mathrm{Ci} / g a 1$. The solids admixed with this solution yield a total volume of approxinately $120,000 \mathrm{gal}\left(\sim 454 \mathrm{~m}^{3}\right.$ ) of grout mixture. The injection well is prepared for a hydrofracture operation by using an abrasive jet to create a radial slot through the metal. casing and cement at a predetermined elevation and, typically, at $10 \mathrm{ft}$ intervals in the: red shale formation. The fracture is initiated by water pressure and then propagated by the grout mixture at a flow rate of about $250 \mathrm{gal} / \mathrm{min}$. Hydraulic pressures necessary for fracture, which are dependent on the well condition following the slitting operation, ${ }^{10}$ have varied between 2000 to $5000 \mathrm{psi}$. The grout mixture is admitted to the injection well. 
through a concentric pipe and is discharged in the near vicinity of the formation fracture plane. The annulus remains filled with water during the service life of the well.

After the grout injection has been completed, the pressure at the wellhead decreases to about 1000 psi during grout solidification ( $24 \mathrm{hr}$ ). During the next 30 days, the overpressure on the sealed wellhead will diminish as formation stresses are relieved.

In the present hydrofracture facility, grout injections were initially made at a depth of about $1000 \mathrm{ft}$. In successive grout injcctions, the borehole below the fracture plane was filled with grout. The borehole above this level remains filled with water. Hence, the solidified grout in the fracture planes is maintained under a hydrostatic head during the service life of the injection well and will be permanently sealed from the atmosphere by grout backfill at the conclusion of this period.

\section{WASTE DISPOSAL OPTIONS}

The volatile radioactive wastes considered for disposal hy the hydrofracture process include ${ }^{129} \mathrm{I}$ as either $\mathrm{I}_{2}$ or $\mathrm{CH}_{3} \mathrm{I},{ }^{14} \mathrm{C}$ as $\mathrm{CO}_{2}$ or an insoluble carbonate, ${ }^{85} \mathrm{Kr}$ as an admixture with xenon, and tritium as tritiated water. The primary development efforts associated with the disposal of these materials have been oriented toward their immobilization in forms that can be contained within retrleval storage facilities. However, the qualification of the hydrofracture process for their permanent disposal could alleviate some of the restrictions placed on these inmobilized materials and could, in some instances, reduce costs incurred by their chemical and/or physical transformation into forms suitable for long-term storage.

\subsection{Immobilization of Volatile Wastes}

Processes to immobilize these volatile radioactive wastes have been reasonably well developed. Iodine, as either $\mathrm{I}_{2}$ or $\mathrm{CH}_{3} \mathrm{I}$, can be oxidized to its iodate form and prepared as solid barium iodate. ${ }^{11}$ An alternate 
process would provide for its absorption and retention on metal-exchanged zeolites. $^{12}$ Carbon-14, present in process off-gas streams as $\mathrm{CO}_{2}$, can be separated by caustic scrubbing and precipitated as calcium carbonate. ${ }^{13}$ Krypton-85 may be isolated from process off-gas streams by cryogenic distillation ${ }^{14}$ or by selective absorption with xenon in the Fluorocarbon Absorption Process. ${ }^{15}$ The products from these separations processes may be stored directly as compressed gases or encapsulated in zeolites by a high-temperature, high-pressure process. ${ }^{16}$ Fuel reprocessing schemes generally recover tritium as tritiated water, which may be held on solid sorbents and stored within sealed containers. The suitability of disposal methods for this material depends on its concentration to manageable storage volumes. 17

\subsection{Volatile Waste Disposal by the Hydrofracture Process}

The disposal of these radioactive wastes by the hydrofracture process may be considered on the basis of their delivery to the wellhead site as liquids, solids, or gases.

\subsubsection{Disposal as liquids}

The current operations of the hydrofracture facility optimize the disposal of aqueous waste solutions. Thus, within volumetric limitations, existing terhnnlngy can be used to commit tritiated water for direct disposal. The direct disposal of iodine and carbon dioxide as solutes in aqueous solution may be feasible provided that their stability in aqueous wastes can be established. The dissolution of noble gases in aqueous wastes may also qualify their disposal by liquid disposal techniques. However, their concentrations in reasonable aqueous volumes will require pre-equilibration with their gaseous phase at relatively high pressures. The use of nonaqueous liquids to improve noble gas solubility values, and perhaps those of iodine and $\mathrm{CO}_{2}$, will require an evaluation of their suitability as a component of the grout mixture. Although improved solubilities may be possible with nonaqueous solvents, the dissolution of noble gases should remain a function of their partial pressures in a contiguous gas phase. 


\subsubsection{Disposal as solids}

Demonstration of the disposal of radioactive solids by the hydrofracture process is planned in the Oak Ridge facility using the sludge component of the intermediate-level wastes generated at ORNL. ${ }^{18}$ This proposed operation will inject the radioactive sludge as a slurry into the grout stream. Conceivably, the disposal of ${ }^{129} \mathrm{I}$ as barium iodate and ${ }^{14} \mathrm{C}$ as calcium carbonate could also be accomplished by this slurry technique. Unfortunately, solid zeolite sorbents used for the encapsulation of kryption are not compatible with aqueous process streams. 19 Therefore, an evaluation of krypton release rates from these structures under simulated hydrofracture process conditions would be necessary before this disposal method could be adapted.

As an alternate proposal, solid wastes can be pelletized before addition to the grout mixture. 20 The development of this technique would also support the direct disposal of krypton-bearing zeolites. Iodine and carbon dioxide, either as pellets of barium iodate and calcium carbonate or as absorbed species on a solid pellet substrate, could also be qualified for disposal by this technique.

\subsubsection{D1sposal as gases}

The direct entrainment of radioactive gases in the grout stream would represent a further development of the hydrofracture process for its application as a general waste disposal technique. In relation to other options, this method would simplify process operating procedures and should not compromice radiation safety control practices. The gaseous wastes can be metered from their storage containers and, after compression, can be injected directly into the discharge stream from the grout pump. In addition, gas injection rates and intervals could be varied while maintaining rigid control over other process parameters.

The qualification of the hydrofracture process for waste disposal by gas entrainment would provide a direct method for the permanent disposal of ${ }^{85} \mathrm{Kr}$, and possibly iodine as $\mathrm{I}_{2}$ or $\mathrm{CH}_{3} \mathrm{I}$, and ${ }^{14} \mathrm{C}$ as $\mathrm{CO}_{2}$. 


\section{ENTRAINMENT OF KRYPTON IN HYDROFRACTURE GROUTS}

Of the three options available for the disposal of volatile radioactive wastes by the hydrofracture method, that of direct gas entrainment will provide greatest utility of the process. In addition, the field demonstration of this waste disposal technique could be accomplished in the existing ORNL facility after minor modifications to the plant equip-. ment and operating procedures. Furthermore, direct gas entrainment is presently the only apparent method for the disposal of krypton by this process. Consequently, this assessment of the feasibility of volatile radioactive waste disposal by the hydrofracture process was based on the disposal of krypton by this method. For reference purposes, this study has arbitrarily considered the disposal of the annual krypton production from a fuel reprocessing capability of 1500 metric tons of uranium by a single injection during a typical hydrofracture operation at ORNL.

$$
4.1 \text { Production of }{ }^{85} \mathrm{Kr}
$$

The Barnwell Nuclear Fuel Plant* was deșigned to reprocess 1500 metric tons of spent fuel per year. The operation of this plant at full capacity would yleld an estimated $16 \mathrm{MCi}$ of ${ }^{85} \mathrm{Kr}$ from head-end operations. ${ }^{3}$ The cumulative volume $\left(0^{\circ} \mathrm{C}, 1 \mathrm{~atm}\right)$ of this off-gas stream would consist of approximately $150 \mathrm{~m}^{3}$ of krypton $\left(210 \%{ }^{85} \mathrm{Kr}\right), 1500 \mathrm{~m}^{3}$ of xenon, and about $1.5 \times 10^{6} \mathrm{~m}^{3}$ of air. If the spent fuel was cooled for 140 to 180 days before processing, the radioactivity associated with this stream would be essentially that of ${ }^{85} \mathrm{Kr}$. Clearly, this cumulative volume is too excessive to be considered for direct disposal by the hydrofracture method.

Although intermediate processing of this off-gas stream by cryogenic distillation would minimize the volume of contained krypton, the Fluorocarbon Absorption Process was chosen for this study because it represents a more realistic appraisal. of the Barnwell plant. The end product should contain krypton as a $50 \%$ mixture in either xenon or argon. 21 This process is also capable of removing iodine as either $\mathrm{I}_{2}$ or $\mathrm{CH}_{3} \mathrm{I}$, and ${ }^{14} \mathrm{C}$

*0wned by Allied-General Nuclear Services, Inc. 
as $\mathrm{CO}_{2} \cdot 22$ Based on this product stream composition, the annual production of krypton can be contained in approximately $300 \mathrm{~m}^{3}\left(0^{\circ} \mathrm{C}, 1 \mathrm{~atm}\right)$, with a ${ }^{85} \mathrm{Kr}$ activity of about $5.3 \times 10^{4} \mathrm{Ci} / \mathrm{m}^{3}$.

\subsection{Krypton Solubility in Grout Mixes}

Although direct measurements are not available, the solubility of krypton in grout mixtures may be assumed from values of its solubility in the aqueous component. The value for aqueous solvents has been. estimated $^{3}$ at approximately $1.4 \times 10^{-5}$ mole fraction per atmosphere of krypton gas pressure over a temperature range of 25 to $50^{\circ} \mathrm{C}$ and pressures to $200 \mathrm{~atm}$. Corresponding coefficients for xenon solubility are not available at these pressures, but xenon solubilities are expected to exceed those of krypton. Thus, the value estimated for krypton solubility should represent the minimum solubility value for the krypton-xenon gas mixture in the aqueous phase of the grout mixtures. Based on an aqueous volume of $80,000 \mathrm{gal}\left(303 \mathrm{~m}^{3}\right)$ per grout injection, the annual production of a krypton-xenon gas mixture can be dissolved in the grout mixture at a total pressure of about 56.8 atm (835 psia).

\subsection{Gas Injection Parameters}

As noted in Sect. 2.2 of this, report, a grout injection pressure of 2000 to 5000 psi (136 to $340 \mathrm{~atm}$ ) is required for propagation of the fracture plane in the Conasauga formation shale. Comparison of the pressure range with that estimated for complete dissolution of the kryptonxenon mixture ( $257 \mathrm{~atm}$ ) will illustrate the equivalence of the dirert gas injection method with that of injecting a krypton-saturated liquid phase. At these excessive pressures, the rapid dissolution of the kryptonxenon mixture entrained in the grout stream can be reasonably assured. For a total grout mixture volume of about 120,000 gal $\left(454 \mathrm{~m}^{3}\right)$, the kryptonxenon injection rate under standard conditions would be approximately 0.63 std $\mathrm{m}^{3} / \mathrm{min}$ for its uniform dispersal in the grout mixture, based on a grout injection rate of $250 \mathrm{gal} / \mathrm{min}$. Under these conditions, the radiation level from ${ }^{85} \mathrm{Kr}$ decay would be approximately $133 \mathrm{Ci} / \mathrm{gal}$ of grout 
mixture. At a power output of $0.574 \mathrm{~W} / \mathrm{g}$ of ${ }^{85} \mathrm{Kr}$, this concentration of krypton will correspond to a power output of about $0.27 \mathrm{~W}$ per gal of grout mixture. 23

At the conclusion of the grout injection period, the overpressure at the wellhead will diminish to about 1000 psi (68 atm) for grout solidification. Considering the hydrostatic pressure head at the bottom of the borehole, the total pressure on the grout mixture in the fracture plane should be approximately 1450 psi (99 atm) and should be more than adequate for maintaining the krypton-xenon mixture as a dissolved phase. Although the grout mixture was developed to retain all of its moisture after solidification, the behavior of the dissolved noble gas mixture during grout solidification cannot be adequately assessed. However, its total release as dispersed gas voids would correspond to less than 1 vol \% of the solid grout.

\subsection{Release Rate Considerations}

A preliminary evaluation of potential ${ }^{85} \mathrm{Kr}$ release rates from a hydrofracture operation performed under reference conditions* considered the back diffusion of krypton into the borehole from solidified grout fixed in the shale fracture. As an initial. condition, the kryptonbearing grout mixture was bound by the borehole and the outer periphery of the fracture plane. The connerting voids in the solidified grout mixture (estimated porosity, 27\%) were assumed to be filled with water. Under these conditions, krypton would diffuse as a dissolved species in the continuous aqueous phase. Considering an initial concentration of ${ }^{85} \mathrm{Kr}$ dissolved in the aqueous phase of $0.54 \mathrm{std} \mathrm{cm}^{3}$ per $\mathrm{cm}^{3}$ of water at a hydrostatic pressure of about $31 \mathrm{~atm}$, the cumulative annual release of ${ }^{85} \mathrm{Kr}$ into the borehole was estimated at $\sim 7 \mathrm{~cm}^{3}$ (STP). Although a quantitative assessment of ${ }^{85} \mathrm{Kr}$ release rates to the atmosphere cannot be assigned from this preliminary evaluation, the relatively low value obtained for krypton diffusion to the borehole should stimu1are further investigation of this waste disposal technique. *Conducted by J. T. Holdeman, Computer Sciences Division, ORNL. 
In actual practice, the krypton reiease rates can be more adequately controlled by varying the initial ${ }^{85} \mathrm{Kr}$ concentration in the grout mixture and increasing its radial distance from the borehole. A detailed study of this complex diffusion process and supporting experimental data on actual diffusion rates through solidified grout mixtures should define this phenomenon in terms of a process operating parameter. These results may be verified by evaluating krypton release rates following the field demonstration of the disposal method.

\section{CONCLUSIONS AND RECOMMENDATIONS}

This report has reviewed the hydrofracture process at ORNL with respect to its application for the disposal of volatile radioactive wastes. The basic technology of this process provides for the mixing of an aqueous stream with a mixture of dry cementaceous solids to form a grout. This mixture is injected into a deep well at pressures sufficient to create fracture planes in the selected geological rock formation. Thus the storage reservoir is created as thin radial sheets in which radioactive wastes are imbedded in a solidified grout mixture. The disposal of volatile radioactive wastes by this process will depend on their inclusion in the grout mixture as liquids, solids, or entrained gases. Although volatile wastes may be immobilized and disposed of as slurries or solid pellets according to a current development program, we recommend that additional research be conducted to establish the feasibility of disposal as entrained gases. This extension of the hydrofracture technology could provide more versatile application of the disposal method, may simplify the handling of volatile radioactive wastes at the wellhead, and may reduce costs associated with disposal operations by elimination of intermediate process steps.

As a basis for this recommendation, the disposal of ${ }^{85} \mathrm{Kr}$ obtained from reprocessing 1500 metric tons of spent fuel during a typical hydrofracture operation was arbitrarily chosen for reference purposes. This disposal rate will yield very low gas voids in the solidified grout mixture, but the permissible disposal rates may be controlled at a lower rate by consideration of allowable radiation intensity levels and power output concentrations from ${ }^{85} \mathrm{Kr}$ decay. Respective values of $133 \mathrm{Ci} / \mathrm{gal}$ and 0.27 
W/gal, which were calculated for the reference disposal rate, exceed those approved for current hydrofracture operations. However, disposal rates that would be permitted on the basis of these two parameters will be independent of the method chosen for combining the volatile wastes with the hydrofracture grout mixture. The direct gas injection method should provide a more versatile control over these parameters than the other disposal options.

The direct gas injection method will necessitate the addition of a gas compressor to the equipment line at the hydrofracture facility. Because of the high-pressure requirement (>5000 psi) to guarantee gas injection under extreme formation fracturing conditions, this equipment unit will represent a major capital investment. Based on a tentative evaluation, a compressor powered by a 600-hp motor at an estimated cost of $\$ 100,000$ will be necessary for gas injection service. The cost of this machine can be amortized over a long-service life; however, the value of its use for intermittent operations during this period may warrant further fiscal evaluation.

Development of a direct gas injection capability for the hydrofracture process will require an experimental engineering program to assign equipment requirements and operating procedures for the field demonstration exercise. Associated laboratory programs will be necessary to assess the behavior of entrained gases during process operations and to evaluate gas release rates to the atmosphere. The recommended program for this process development activity may be outlined by the following tasks:

1. develop a coordinated experimental plan that will lead to a field demonstration of gas infection technology;

2. design, fabricate, and operate a prototype engineering facility for shakedown and cold testing of the gas injection method;

3. examine entrained gas behavior under grout transport conditions and after grout solidification;

4. measure the diffusivity of volatile radioactive wastes through solidified grout;

5. assess radiation safety of the disposal method based on performance of the prototype engineering facility and gas release rates calculated 
for their diffusion through solidified grout and surrounding geological formations; and

6. provide field demonstrations of the gas injection method.

\section{ACKNOWLEDGMENTS}

The availability of the Dames and Moore report in draft form, cited as ref. 3, has facilitated the collection of data necessary for this appraisal. The authors also acknowledge the assistance of $\mathrm{H}$. 0 . Weeren in identifying those operating parameters of the hydrofracture process which will influence its adaptability for disposing of volatile materials. J. T. Holdeman provided a preliminary analysis of the krypton release rates. Thelma Patton was responsible for the organization and preparation of the manuscript.

\section{REFERENCES}

1. Subgroup Report on Alternate Technology Strategies for the Isolation of Nuclear Waste, TID-28818 (Draft), Interagency Review Group on Nuclear Waste Management (October 1978).

2. H. U. Weeren, INuc1. Eng. Des. 44, 291 (1977).

3. R. M. Winar, L. E. Trevorrow, and M. J. Steindler, Feasibility of Underground Storage/Disposal of Noble Gas Fission Products, ANL-78-81 (in publication, 1978); based on a feasibility study by Dames and Moore (Draft), Park Ridge, Ill.

4. H. 0. Weeren, An Evaluation of Waste Disposal by Shale Fracturing, ORNL/TM-5209 (February 1976).

5. W. De Laguna, Nucl. Ëng. Des. $\underline{3}, 338$ (1966).

6. W. De Laguna, Nuc1. Eng. Des. 3 , 432 (1966).

7. H. O. Weeren, Nuc1. Eng. Des. 4, 108 (1966).

8. T. Tamura, Nuc1. Eng. Des. $\underline{5}, 477$ (1967).

9. R. E. Lampton, R. A. Robinson, and H. O. Weeren, Conceptual Design Report - New Hydrofracture Facility, ORNL/TM-4826 (July 1975).

10.. H. O. Weeren, private communication, September 1978. 
11. W. E. Clark, Nuc1. Technol. 36, 215 (December 1977).

12. D. T. Pence and B. A. Staples, "Solid Sorbents for Collection and Storage of Iodine-129 from Reprocessing Plants," Proceedings of the 13th AEC Air Cleaning Conference, CONF-740807, p. 758 (August 1974).

13. A. G. Croff, An Evaluation of Options Relative to the Fixation and Disposal of $14 \mathrm{C}$ - Contaminated $\mathrm{CO}_{2}$ as $\mathrm{CaCO}_{3}$, ORNL/TM-5171 (Apri1 1976).

14. B. A. Foster, D. T. Pence, and B. A. Staples, "Long Term Storage Techniques for ${ }^{85} \mathrm{Kr}$," Proceedings of the 13th AEC Air Cleaning

- Conference, CONF-740807, pp. 293-98 (August 1974).

15. M. J. Stephenson et al., "Experimental Demonstration of the Selective Absorption Process for Krypton-Xenon Removal," Proceedings of the Twelfth AEC Air Cleaning Conference, CONF-720823, p. 11 (January 1973).

16. R. M. Barrer and D. E. W. Vaughen, J. Phys. Chem. Solids 32, 730-743 (1971).

17. Alternatives for Managing Wastes from Reactors and Post-Fission Operations in the LWR Fuel Cycle, ERDA-76-43, vol. 2, p. 14.9 (May 1976).

18. H. O. Weeren, J. G. Moore, and E. W. McDanie1, "Waste Disposa1 by Shale Fracturing at ORNL," Proceedings of the Symposium of Science Underlying Radioactive Wastes Management, Boston, Mass., Nov. 29Dec. 1, 1978.

19. R. W. Benedict, An Evaluation of Methods for Immobilizing Solids Loaded With Krypton-85, ICP-1130 (August 1977).

20. H. O. Weeren, private communication, Nov. 9, 1978.

21. M. J. Stephenson, private communication, July 21, 1978 .

22. M. J. Stephenson and R. S. Eby, Development of the FASTER Process for Removing Krypton-85, Carbon-14 and Other Contaminants from the offGas of Fuel Reprocessing P1ants, K-GD-1398 (1976).

23. A. B. Christensen, Physical Properties and Heat Transfer Characteristics of Materials for Krypton-85 Storage, ICP-1128 (September 1977). 


\section{THIS PAGE}

\section{WAS INTENTIONALLY \\ LEFT BLANK}


ORNL/TM-6931

Dist. Category UC-70

\section{INTERNAL DISTRIBUTION}

$\begin{aligned} & \text { 1. } \text { C. W. Alexander } \\ & 2 . \text { S. I. Auerbach } \\ & 3 . \text { R. E. Blanco } \\ & \text { 4-5. } . \text { O. Blomeke } \\ & \text { 6. L. A. Boatner } \\ & \text { 7. } \text { W. D. Burch } \\ & 8 . \text { F. N. Case } \\ & 9 . \text { A. G. Croff } \\ & \text { 10. B. C. Finney } \\ & \text { 11. R. B. Fitts } \\ & \text { 12. E. J. Frederick } \\ & \text { 13. H. W. Godbee } \\ & \text { 14. K. W. Haff } \\ & \text { 15. V. A. Jacobs } \\ & \text { 16. G. H. Jenks } \\ & \text { 17. E. H. Kobisk } \\ & \text { 18. T. F. Lomenick }\end{aligned}$

\author{
19. A. L. Lotts \\ 20. R. S. Lowrie \\ 21. A. P. Malinauskas \\ 22. W. C. McClain \\ 23. J. G. Moore \\ 24. E. Newman \\ 25. H. A. Pfuderer \\ 26. R. A. Robinson \\ 27-31. J. H. Shaffer \\ 32. T. Tamura \\ 33. H. O. Weeren \\ 34. R. G. Wymer \\ 35-39. Laboratory Records \\ 40. Laboratory Records - RC \\ 41-42. Central Research Library \\ 43. ORNL Patent Section \\ 44. Document Reference Section
}

\section{EXTERNAL DISTRIBUTION}

45-46. Director, Division of Nuclear Power Development, Department of Energy, Washington, D.C. 20545

47. Office of Assistant Manager, Energy Research and Development, Department of Energy, Oak Ridge Operations, Oak Ridge, Tenn. 37830

48. Director, Nuclear Research and Development Division, Department of Energy, Oak Ridge Operations, Oak Ridge, Tenn. 37830

49. C. B. Bartlett, Chief, Fuel Cycle Research Branch, Division of Fuel Cycle and Environmental Research, U.S. Nuclear Regulatory Commission, Mail Stop SS 1130, Washington, D.C. 20555

50. W. F. Bennett, Rocky Flats Area Office, P.0. Box 928, Golden, Colo. 80401

51. R. M. Bernero, Assistant Director for Materials Safety Standards, Division of Engineering Standards, U.S. Nuclear Regulatory Commission, Washington, D.C. 20555

52. W. F. Bonner, Pacific Northwest Laboratories, Battelle Boulevard, Ri.chland, Wash. 99352

53. R. F. Bradley, Savannah River Plant, E. I. du Pont de Nemours \& Co., Inc., Aiken, S. C. 29801

54-58. R. A. Brown, Allied Chemical Corp., 550 Second Street HQ330, Idaho Falls, Idaho 83401

59. J. A. Buckham, Allied-General Nuclear Services, P. O. Box 847, Barnwe11, S. C. 29812

60. W. A. Carbiener, Battelle Memorial Institute, Office of Nuclear Waste Isolation, 505 King Ave., Columbus, Ohio 43201 
61. A. B. Carson, FBR-Department, Energy R and T Division, General Electric Company, 175 Curtner Avenue, San Jose, Calif. 95100

62. N. E. Carter, General Manager, Battelle Memorial Institute, Office of Nuclear Waste Isolation, 505 King Ave., Columbus, Ohio 43201

63-64. J. L. Crandall, Director of Planning, Savannah River Laboratory, Aiken, S. C. 29801

65. G. H. Daly, Chief, Technology Branch, Division of Waste Products, Office of Nuclear Waste Management, Ma11 Stop B-107, Department of Energy, Washington, D. C. 20545

66. R. Danford, Attn: Input Processing Division, Institute Research and Evaluation, 21098 IRE Control Center, Eagen, MN 55121

67. J. E. Dempsey, Technology Branch, Division of Waste Products, Office of Nuclear Waste Management, Department of Energy, Washington, D. C. 20545

68. J, E. Dieckhoner, Chief Operations Branch, Division of Waste Products, Office of Nuclear Waste Management, Department of Energy, Washington, D.C. 20545

69. J. P. Duckworth, Nuclear Fuel Services, Inc., P.0. Box 124, West Valley, N. Y. 14171

70. R. G. Garvin, Savannah River Laboratory, Aiken, S. C. 29801

71. E. S. Goldberg, Chief of Waste Management, Savannah River Operations Office, P.O. Box A, Aiken, S. C. 29801

72. W. J. Haubach, Division of Physical Research, Department of Energy, Washington, D. C. 20545

73. J. F. Hayes, Delaware Custom Material, Inc., 21380 Lorain Rd., Cleveland, Ohio 44126

74. C. A. Heath, Director, Division of Waste Isolation, Office of Nuclear Waste Management, Department of Energy, 400 First Street N. W., Washington, D. C. 20545

75. L. R. Hill, Bupervisor, Nuclear Waste Technology Divison, Sandia Laboratories, Albuquerque, N. M. 87115

76. E. R. Irish, Pacific Northwest Laboratories, Battelle Boulevard, Richland, Wash. 99352

77. E. Jardine, Argonne National Laboratory, Chemical Engineering Divislon, Argunie, I11. 60439

78. J. H. Jarrett, Pacific Northwest Laboratories, Battelle Boulevard, Richland, Wash. 99352

79. J. L. Landon, Program Manager, ET-Decontamination and Decomm1ssioning Program, Richland, Wash. 99352

80-89. D. E. Large, Department of Energy, Oak Ridge Opcrationo, Oak Ridge, Tenn. 37830

90. W. H. Lewis, Vice President, Nuclear Fuel Services, Inc., 6000 Executive Blvd., Rockville, MD 20852

91. R. Y. Lowrey, Chief, Waste Management Branch, Albuquerque Operations offlce, P.0. Bux 5400, Alluquerque, N. M. 87115

92. J. Martin, Director for Waste Management, Division of Fuel Cycle and Material Safety, U.S. Nuclear Regulatory Comission, Washington, D. C. 20555

93. J. E. Mendel, Pacific Northwest Laboratories, Battelle Boulevard, Richland, Wash. 99352 
94. L. H. Meyer, Savannah River Laboratory, E. I. du Pont de Nemours \& Co., Inc., Aiken, S. C. 29801

95. G. J. McCarthy, Pennsylvania State University, Materials Research Laboratory, University Park, Pa. 16802

96. J. L. McElroy, Pacific Northwest Laboratories, Battelle Boulevard, Richland, Wash. 99352

97. A. D. Miller, EPRI, 3412 Hillview Ave., P.o. Box 10412, Palo Alto, Calif. 94303

98. M. A. Molecke, Nuclear Waste Technology Division, Sandia Laboratories, Albuquerque, N. M. 87115

99. J. W. Nehls, Department of Energy, Oak Ridge Operations, Oak Ridge, Tenn. 37830

100. J. Neff, Department of Energy, Richland-Columbus Project Office, 505 King Ave., Columbus, Ohio 43201

101-115. G. Oertel, Director, Division of Waste Products, Office of Nuclear Waste Management, Department of Energy, Washington, D. C. 20545

116. D. A. Orth, Savannah River Plant, E. I. du Pont de Nemours \& Co., Inc., Aiken, S. C. 29801

117. A. M. Platt, Pacific Northwest Laboratory, P.0. Box 999, Richland, Wash. 99352

118. D. M. Roy, Materials Research Laboratory, Pennsylvania State University, University Park, Pa. 16802

119. R. Roy, Materials Research Laboratory, Pennsylvania State University, University Park, Pa. 16802

120. A. R. Sattler, Nuclear Waste Technology Division, Sandia Laboratories, Sandia, N. M. 87115

121. L. W. Scully, Nuclear Waste Technology Division, Sandia Laboratories, Sandia, N. M. 87115

122. J. J. Shefcik, General Atomic Company, P.0. Box 81608, San Diego, Calif. 92138

123. M. J. Steindler, Argonne National Laboratory, 9700 South Cass Ave., Argonne, I11. 60439

124. D. K. Stevens, Assistant Director for Materials Sciences, Division of Physical Research, U. S. Department of Energy, Washington, D. C. 20545

125. R. E. Tomlinson, Manager, Exxon Nuclear Company, Inc., 2101 Horn Rapids Road, Richland, Wash. 99352

126-130. J. B. Whitsett, Chief of Radioactive Waste Management, Idaho Operations Office, Department of Energy, 550 2nd Street, Idaho Falls, Idaho 83401

131. M. C. Wittels, Division of Materials Science, Offlce of Bastc Energy Science, Mail Stop J309, Department of Energy, Washington, D. C. 20545

132-464. Given distribution as shown in TID-4500 under the Nuclear Waste Management Category 